\title{
DOES RAILWAY LINES INVESTMENTS MATTER FOR ECONOMIC GROWTH?
}

\author{
Prince Fosu ${ }^{1 \star}$ \\ date of paper receipt: \\ date of sending to review: \\ date of review receipt: \\ 04.01.2021. \\ 27.01.2021. \\ 31.12.2020. \\ doi: 10.2478/eoik-2021-0004 \\ UDK 656.2+625.1]:338.22 \\ Original Article
}

${ }^{1}$ School of Analytics, Finance and Economics, Southern Illinois University Carbondale, Illinois, USA, e-mail: prince.fosu@siu.edu

\begin{abstract}
The \$20.81 trillion U.S. economy relies on a vast infrastructure network to thrive; however, empirical studies that examined that impact of infrastructure on economic growth in the U.S. are limited. This study's principal objective was to examine the effect of railway lines on economic growth using annual data from 1980 to 2016 and cointegration analysis. The results showed a positive and significant impact of railway lines on economic growth in the long-run and short-run. The impulse response analysis indicates that shocks to railway lines initially cause GDP growth rates to increase and decrease continuously. The variance decomposition analysis also suggests that overtime, railway lines contribute largely to the variations in economic growth followed by inflation and population. This study's outcome has important implications not only for the U.S. economy but also for developing and emerging countries. The results suggest that railway lines investments matter for economic growth in the U.S.
\end{abstract}

\section{Keywords:}

economic growth, railway lines, VECM, United States.

JEL Classification: EOO, H54, O4O, 018 


\section{INTRODUCTION}

Infrastructure network from roads and bridges to freight rail and ports to electrical grids and internet provision plays a critical role in every nation's growth and prosperity. It also improves households' social and economic welfare. Studies have shown that available and quality infrastructure enhances economic growth in both developed and developing (Canning \& Pedroni, 2004; Holtz-Eakin \& Schwartz, 1995; Fosu, 2019). Armah and Fosu (2016) also found that investment in economic and social infrastructure leads to increased private investments which is positively related to economic growth. On the contrary, poor infrastructure imposes high costs to the country's economy and poses a serious threat to human safety (McBride \& Moss, 2020). A study by the University of Maryland in 2014 found that every dollar spent on infrastructure investments added \$3 to GDP growth, with a more significant effect during a recession. More so, a global consulting firm, McKinsey, estimated that a 1 percent of GDP increase in U.S. infrastructure spending adds 1.5 million jobs to the economy (McBride \& Moss, 2020).

Globally, spending on necessary infrastructure amounts to $\$ 2.7$ trillion a year when it should be $\$ 3.7$ trillion (World Economic Forum report 2016). For instance, Asia alone will need more than $\$ 700$ billion annually to meet its infrastructure gap through 2020 (Center for Strategy and International Studies, CSIS, 2020). Increased global demand for infrastructure is due to rapid population growth, rapid urbanization, and economic and industrial expansion, among others (CSIS, 2020). The U.S. population had increased dramatically since the 1960s, when most of its infrastructure was designed (McBride \& Moss, 2020). As a result, many of the country's infrastructure are reaching their lifespan and are dangerously overstretched (McBride \& Moss, 2020). Even though the U.S. is the world's largest economy, the country still lags behind its peers in other advanced countries (McBride \& Moss, 2020). The World Economic Forum's Global Competitiveness Report indicated that in 2019, the U.S. ranked $13^{\text {th }}$ globally in a broad measure of infrastructure quality, down from $5^{\text {th }}$ place in 2002. Specifically, this measure places the U.S. behind countries such as France, Germany, Japan, Spain, the UAE, and the U.K. (The World Economic Forum report 2019).

Total infrastructure needs in the U.S. between 2016 and 2025 is projected to be $\$ 4,590$ billion, while actual spending amount to $\$ 2,526$ billion. As a result, most of America's roads, bridges, and dams are rated D+ (ASCE, 2017). McKinsey researchers have also indicated that the U.S. economy requires about $\$ 150$ billion per year between 2017 and 2030 to meet the country's infrastructure needs (McBride \& Moss, 2020). For instance, in the U.S., the railway industry alone requires $\$ 200$ billion in investment by 2035 to meet projected future demand (Dovell 2012). The Figure 1 shows that total rail lines $(\mathrm{km})$ has declined from $201,284 \mathrm{~km}$ in 1995 to $150462.29 \mathrm{~km}$ in 2018 . Aside from population growth, the federal government's inadequate infrastructure investment has contributed to the massive infrastructure deficit in the U.S. (ASCE, 2017). The deteriorating effect of the insufficient infrastructure gap has led to a loss of available jobs, declining growth, and reduction in household income and welfare.

Previous studies have analyzed the relationship between infrastructure and growth; however, most of these studies focused on cross-country analysis with few studies on country-specific analysis. More so, to my knowledge, empirical studies that examine the effect of railway network on economic growth in the U.S. are limited although, in 2017 alone, railroads supported approximately 1.1 million jobs, nearly $\$ 219.5$ billion in economic output, $\$ 71.3$ billion in wages, and $\$ 26$ billion in tax revenues to the U.S. economy (Association of American Railroads report 2020). Therefore, this study's main objective is to examine the effects of railway lines on economic growth in the United States in the long-run and short-run. The outcome of this study is expected to contribute to both empirical literature and policy formulation. The remaining part of this study is organized 
as follows. The first section presents the literature review, section two focuses on the methodology, section three presents the results, section four presents the discussions, while the last section offers the conclusion.

Figure 1. Trend in Rail lines (total route-km) in the U.S. from 1995 to 2018

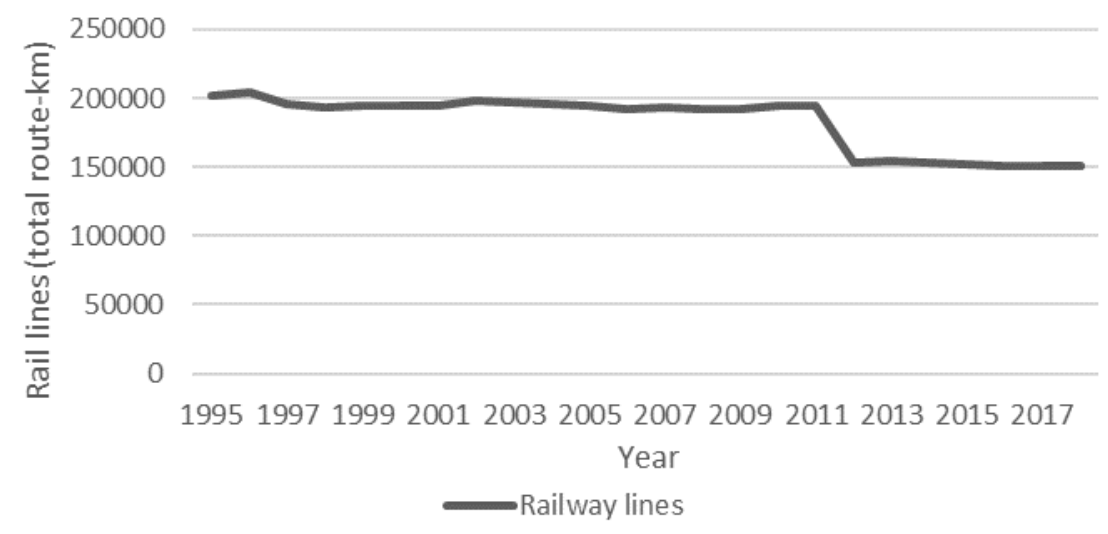

Source: World Bank (2020)

\section{LITERATURE REVIEW}

This section of the study presents the literature review on the relationship between infrastructure and economic growth. Employing a panel of countries over the period 1950-1992, Canning and Pedroni (2004) examined the long-run effects of infrastructure provision on per capita income. Their study found that infrastructure does induce long-run growth effects; however, a significant variation was found in the results across individual countries.

The study by Aschauer (1989) also examined the relationship between aggregate productivity and stock and flowed government-spending variables. It was observed that the nonmilitary public capital stock was significant in influencing productivity than is either the flow of nonmilitary or military expenditure. More so, military capital bears little relation to productivity. Lastly, the 'core' infrastructure of streets, highways, airports, mass transit, sewers, water systems, among others, has the most explanatory power for productivity.

Also, in Pakistan, Alam et al. (2020) employed the autoregressive distributed lag (ARDL) and vector error correction model (VECM) over the period 1971-2017 to examine the relationship between transport infrastructure and economic development. The study finds that that transport infrastructure had a long-run positive impact on economic growth. More so, the Granger causality test shows a unidirectional causality running from transport infrastructure to economic development.

In a similar study, Esfahani and Ramirez (2003) employed a cross-country analysis and examined the relationship between institutions, infrastructure, and economic growth. Their study found that the contribution of infrastructure services is significant for GDP growth and also exceeds the cost of provision of those services.

Using a panel of OECD countries from 1996-2007 and Instrumental variable estimation, Czernich, Kretschmer, and Woessmann (2011) estimate the effect of broadband infrastructure on economic growth. They found that a ten-percentage point increase in broadband penetration increases annual GDP per capita growth by $0.9-1.5$ percent. 
More so, Banerjee, Duflo, and Qian (2012) examined the effect of access to transportation networks on China's regional economic outcomes over a twenty-period of rapid income growth. The results showed that proximity to transportation networks tends to moderate a positive causal effect on per capita levels across the sector; however, the study finds no evidence on per capita GDP growth.

Employing time series data from 1958-1988, Cronin et al. (1991) examined the causality between telecommunication infrastructure and economic growth in the U.S. The study found a two-way causality between the U.S. economic activity and telecommunications investment.

In a similar study, Sridhar and Sridhar (2007) used the 3SLS estimation and analyzed the linkage between telephone penetration and economic growth for developing countries. Their study found that traditional economic factors influence demand for mainlines and mobile phones. The study also found a positive impact of mobile and landline phones on output.

Using the U.S. data and multivariate cointegration technique, Lau and Sin (1997) examined whether economic growth is generated endogenously or exogenously due to private and public capital, respectively. Their study found that evidence is unfavorable to the endogenous growth with public infrastructure. The study also found that the estimated elasticity of output with respect to public capital is 0.11 .

Furthermore, Palei (2015) employed both a growth accounting framework and cross-country analysis and analyzed whether infrastructure investment has contributed to East Asia's economic growth. Their research found no significant relationship between infrastructure, productivity, and growth.

\section{METHODOLOGY}

\subsection{THEORETICAL MODEL}

The main objective of this study was to examine the relationship between railway lines and economic growth in the United States. The Solow-Swan growth model was employed as the theoretical framework. The model expresses economic growth as a function of capital accumulation, labor or population growth, and technology or productivity. This is specified in Equation (1);

$$
Y_{t}=K_{t}^{\alpha} L_{t}^{1-\alpha} A_{t}
$$

Where $\mathrm{Y}$ denotes economic growth, $\mathrm{K}$ is capital, $\mathrm{L}$ is labor or population growth, $\mathrm{A}$ is total factor productivity and $t$ is time. It is assumed that technology can be influenced by available railway lines. Therefore, $\mathrm{A}$ is specified as a function of railway lines:

$$
A_{t}=\varphi R A I L_{t}^{\delta} Z_{t}^{\mu}
$$

where $\mathrm{A}$ is technology, RAIL is railway lines, and $\mathrm{Z}$ is other exogenous factors that may influence technology. Putting Equation (2) into Equation (1), Equation (3) is obtained:

$$
Y_{t}=\varphi R A I L_{t}^{\delta} K_{t}^{\alpha} L_{t}^{1-\alpha} Z_{t}^{\mu}
$$

Also, diving both sides by labor and taking logs, Equation (3) can be linearized as follows:

$$
Y_{t}=\vartheta_{0}+\vartheta_{1} K_{t}+\vartheta_{2} L_{t}+\vartheta_{3} R A I L_{t}+\mu_{t}
$$


Y, K, L, RAIL indicate the log of real GDP per capita, log of real capital stock per capita, log of the labor force, and log of railway lines respectively.

\subsection{ECONOMETRIC MODEL AND DATA DESCRIPTION}

The study modified Equation (4) to obtain the empirical model for this study. This is specified by equation (5).

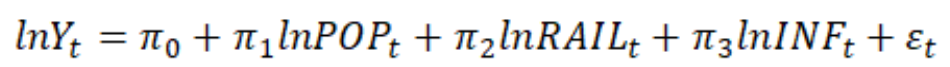

Where $\mathrm{Y}$ is gross domestic product (GDP) per capita growth rates to measure economic growth, POP is population, RAIL indicates railway lines (total-route $\mathrm{km}$ ), INF is inflation consumer prices index (annual \%) $(2010=100), \epsilon_{t}$ is the error term, $\ln$ is the natural logarithm, $\pi_{0}$ is the intercept parameter, $\pi_{1}, \pi_{2}$, and $\pi_{3}$ measures the elasticities. The study relied solely on secondary data from 1980-2016. Data on GDP, population, and inflation were obtained from the World Bank/World Development Indicators (WDI). It was difficult getting all the data on railway lines from the same source and so the data were obtained from two different sources (i.e. from Canning 1998 and World Bank) however, this did not negatively affect the analysis because the unit of measurement of the data were the same (i.e. total-route $\mathrm{km}$ ). Data on railway lines from 1980 to 2000 were obtained from Canning 1998 while the data from 2001 to 2016 were obtained from the World Bank. Economic growth in this study is defined as the increase in the value of all national output or expenditure within a country during a year. It forms an important part of macroeconomic goal because it enables increased standard of living, increased tax revenues, and jobs creation. Economic growth is the outcome variable in this study, and it is measured as the first difference of the log of real per GDP growth.

Higher population can influence economic growth either from the demand side or the supply side. From the demand side, population can increase the can serve as market size or demand of the economy and hence increase growth via consumption. More so, countries with large population are more likely to have available labor needed for production. The study therefore expects the coefficient of population to be positive $\left(\pi_{1}>0\right)$. Railway lines is the main independent variable in this study. The availability and investment in railway lines can increase the productive capacity of the economy because it facilitates the movement of goods and services, provides jobs for the households, and support business growth. The study therefore expects the coefficient of railway lines to impact positively on economic growth $\left(\pi_{2}>0\right)$. Inflation is defined as the persistence and continuous rise in the general price level of the economy. Inflation in this study is measured by the first difference of the log of the consumer price index. Inflation was used to capture for the effect of the macroeconomic environment on economic growth. Inflation is expected to have a negative relationship with economic growth $\left(\pi_{3}<0\right)$. Table 1 provides the summary of the variables used in this study.

Table 1. Summary and Measurement of Variables

\begin{tabular}{lllll}
\hline Variable & Description & Measurement & Source & $\begin{array}{l}\text { Expected } \\
\text { Sign }\end{array}$ \\
\hline GDP & $\begin{array}{l}\text { Gross Domestic } \\
\text { Growth }\end{array}$ & log of real GDP per capita growth & WDI & \\
\hline POP & Population & Log of population, total & WDI & + \\
\hline RAIL & Railway lines & Railway lines (total-route km) & $\begin{array}{l}\text { WDI and Canning } \\
(1998)\end{array}$ & + \\
\hline INF & Inflation & $\begin{array}{l}\text { Consumer Prices Index, inflation } \\
\text { (annual \%) }(2010=100)\end{array}$ & WDI & - \\
\hline
\end{tabular}

Source: Calculated by author(s) 


\section{Estimation technique}

The study employed a dynamic vector autoregressive regression (VAR) estimation because it allows both the long-run and short-run dynamics among the variables to be estimated and addresses the possible endogeneity bias between economic growth and infrastructure. Mathematically, the VAR model is specified below:

$$
Y_{t}=\theta+\xi_{1} Y_{t-1}+\cdots+\xi_{p} Y_{t-p}+\Omega Z_{t}+\varepsilon_{t}
$$

Where $Y_{t}$ indicates the vector of endogenous variables, $Z_{t}$ is a vector of exogenous variables, $\xi_{1} \cdots \xi_{p}$ and $\Omega$ are the matrix of unknown coefficients to be estimated, $\varepsilon_{t}$ is a vector of error terms or innovations. The study determines the optimal lag length using the AIC and SIC criterion. The short-run dynamic coefficients are obtained by estimating an error correction model associated with the long-run estimates. This is specified below:

$$
Y_{t}=\theta+\xi_{1} Y_{t-1}+\cdots+\xi_{p} Y_{t-p}+\Omega Z_{t}+\psi E C M_{t-1}+\varepsilon_{t}
$$

Where $E C M_{t-1}$ denotes the error correction term and $\psi$ indicates the speed of adjustment.

\section{RESULTS}

This section of the paper presents the empirical results. The study's objectives were first to examine both the long-run and short-run relationship between railway lines and economic growth in the U.S. Table 2 presents the summary statistics of the variables used for the analysis. The Table 2 indicates that on average, GDP per capita within the study period is $\$ 41,440.12$, with the minimum and maximum GDP per capita growth around $\$ 28,362.49$ and $\$ 52,364.24$, respectively. Average railway lines is $204,620.0 \mathrm{~km}$, with minimum around $157,515.3 \mathrm{~km}$ and maximum around 265,841.9 $\mathrm{km}$, respectively. The inflation rate within the study period averaged $4.28 \%$, with minimum and maximum inflation averaging $4.70 \%$ and $3.63 \%$. Skewness and Kurtosis test indicate that all the variables are normally distributed.

Table 2. Summary Statistics

\begin{tabular}{lllll}
\hline & GDP & RAIL & POP & INF \\
\hline Mean & 41440.12 & 204620.0 & $2.75 \mathrm{E}+08$ & 4.280994 \\
\hline Median & 42292.89 & 213258.1 & $2.76 \mathrm{E}+08$ & 4.314222 \\
\hline Maximum & 52364.24 & 265841.9 & $3.23 \mathrm{E}+08$ & 4.701089 \\
\hline Minimum & 28362.49 & 157515.3 & $2.27 \mathrm{E}+08$ & 3.632006 \\
\hline Std. Dev. & 7625.379 & 34615.45 & 30343204 & 0.310222 \\
\hline Skewness & -0.233529 & -0.012794 & -0.011560 & -0.375592 \\
\hline Kurtosis & 1.683221 & 1.642415 & 1.663814 & 2.012558 \\
\hline Jarque-Bera & 3.009411 & 2.842359 & 2.753306 & 2.373120 \\
\hline Probability & 0.222083 & 0.241429 & 0.252422 & 0.305270 \\
\hline Sum & 1533285. & 7570940. & $1.02 \mathrm{E}+10$ & 158.3968 \\
\hline Sum Sq. Dev. & $2.09 \mathrm{E}+09$ & $4.31 \mathrm{E}+10$ & $3.31 \mathrm{E}+16$ & 3.464549
\end{tabular}

Source: Calculated by author(s)

Before conducting the cointegration analysis, the unit root test (i.e., ADF and P.P.) on all the variables was performed to examine their stationarity properties (see Table 3 and Table 4 ). The results indicate that all variables are non-stationary at level, but at first differenced, they became stationary. 
Table 3. Unit Root Test-Augmented Dickey-Fuller (Levels)

\begin{tabular}{lllllll}
\hline Var & \multicolumn{2}{c}{ ADF } & Var & \multicolumn{2}{c}{ ADF } & OI \\
\hline & Statistic & P-Value & & Statistic & P-Value & \\
\hline GDP & -1.575061 & 0.4844 & DGDP & -4.071916 & $0.0032^{* * *}$ & $\mathrm{I}(1)$ \\
\hline INF & -1.285550 & 0.6256 & DINF & -5.229337 & $0.0001^{* * *}$ & $\mathrm{I}(1)$ \\
\hline RAIL & -1.740028 & 0.4032 & DRAIL & -5.151709 & $0.0002^{\star * *}$ & $\mathrm{I}(1)$ \\
\hline POP & -2.087603 & 0.2507 & DPOP & -2.514300 & $0.0023^{\star * *}$ & $\mathrm{I}(1)$ \\
\hline
\end{tabular}

Note: $\mathrm{D}$ indicates first differenced. O.I. indicates order of integration.

Source: Calculated by author(s)

Table 4. Unit Root Test-Phillip-Perron ((Levels)

\begin{tabular}{lllllll}
\hline Var & \multicolumn{2}{c}{ P.P. } & Var & \multicolumn{2}{c}{ PP } & OI \\
\hline & Statistic & P-Value & & Statistic & P-Value & \\
\hline GDP & -1.730613 & 0.4078 & DGDP & -3.980499 & $0.0041^{* * *}$ & $\mathrm{I}(1)$ \\
\hline INF & -1.212191 & 0.6585 & DINF & -5.225837 & $0.0001^{* * *}$ & $\mathrm{I}(1)$ \\
\hline RAIL & -1.803546 & 0.3729 & D RAIL & -5.170156 & $0.0002^{* * *}$ & $\mathrm{I}(1)$ \\
\hline POP & 0.028257 & 0.9551 & DPOP & -1.481248 & $0.0031^{* * *}$ & $\mathrm{I}(1)$ \\
\hline
\end{tabular}

Note: $\mathrm{D}$ indicates the first difference. O.I. indicates the order of integration.

Source: Calculated by author(s)

To get the optimal lag order for the VAR estimation, the study employed the lag length selection criterion, and the A.R. Roots graph was performed. The appropriate lag length of 2 was used for the VAR model (see Table 5).

Table 5. Lag Order Selection Criteria

\begin{tabular}{lllllll}
\hline Lag & LogL & LR & FPE & AIC & SC & HQ \\
\hline 0 & 202.9778 & NA & $9.70 \mathrm{e}-11$ & -11.70458 & -11.52501 & -11.64334 \\
\hline 1 & 472.9480 & 460.5373 & $3.18 \mathrm{e}-17$ & -26.64400 & -25.74614 & -26.33780 \\
\hline 2 & 501.3922 & $41.82975^{\star}$ & $1.60 \mathrm{e}-17$ & -27.37601 & $-25.75987^{\star}$ & $-26.82486^{\star}$ \\
\hline 3 & 520.1817 & 23.21054 & $1.52 \mathrm{e}-17^{\star}$ & $-27.54010^{\star}$ & -25.20567 & -26.74399
\end{tabular}

${ }^{*}$ indicates lag order selected by the criterion

Source: Calculated by author(s)

After determining the optimal lag order of 2 , the VAR model of the 2nd order is reestablished (see Table 6). After that, the test of stationarity of the VAR model and mod of A.R. characteristic root reciprocal of VAR model are shown as Figure 2. Since the mod of reciprocal of each characteristic root is in the circle, it suggests that lag order of 2 is appropriate and the established VAR model is stable. 
Table 6. VAR Results

\begin{tabular}{lllll}
\hline & GDP & POP & RAIL & INF \\
\hline GDP(-1) & 0.787182 & 0.001321 & -0.059251 & 0.169337 \\
\hline & {$[6.76773]$} & {$[0.21966]$} & {$[-0.07819]$} & {$[1.47723]$} \\
\hline GDP(-2) & -0.173112 & 0.000802 & 0.143704 & -0.060777 \\
\hline POP(-1) & {$[-1.63832]$} & {$[0.14686]$} & {$[0.20876]$} & {$[-0.58363]$} \\
\hline & -5.382995 & 1.533608 & -6.770448 & -0.120946 \\
\hline POP(-2) & {$[-2.61649]$} & {$[14.4203]$} & {$[-0.50515]$} & {$[-0.05965]$} \\
\hline RAIL $(-1)$ & 5.605462 & -0.595563 & 7.495027 & 0.068383 \\
\hline & {$[2.91687]$} & {$[-5.99516]$} & {$[0.59867]$} & {$[0.03611]$} \\
\hline RAIL $(-2)$ & 0.009688 & -0.000883 & 0.829539 & 0.008404 \\
\hline & {$[0.33126]$} & {$[-0.58374]$} & {$[4.35384]$} & {$[0.29158]$} \\
\hline INF(-1) & -0.102516 & -0.000112 & 0.004492 & -0.003304 \\
\hline & {$[-3.14963]$} & {$[-0.06631]$} & {$[0.02118]$} & {$[-0.10300]$} \\
\hline INF(-2) & -0.672325 & 0.035036 & 0.881448 & 1.130302 \\
\hline C & {$[-3.56764]$} & {$[3.59655]$} & {$[0.71797]$} & {$[6.08588]$} \\
\hline & 0.756679 & -0.014652 & -1.118515 & -0.199743 \\
\hline & {$[5.36658]$} & {$[-2.01024]$} & {$[-1.21768]$} & {$[-1.43742]$} \\
\hline
\end{tabular}

Note: t-Statistic in bracket.

Source: Calculated by author(s)

Figure 2. Inverse Roots of AR Characteristic Polynomial

Inverse Roots of AR Characteristic Polynomial

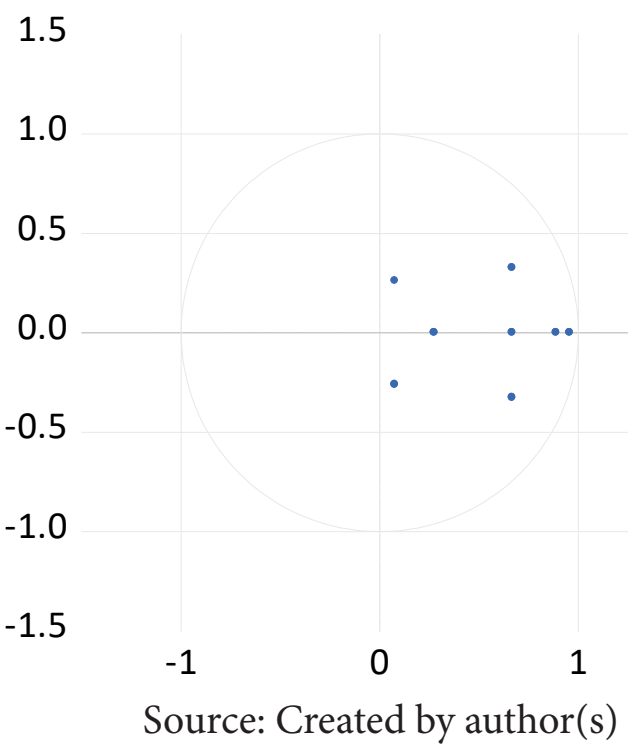

The Johansen cointegration test was performed to determine if the variables have longrun relationship. The test results show the presence of 4 cointegration for both trace statistic and maximum eigenvalue cointegration tests (see Table 7 and 8). This result suggests that the null hypothesis of no cointegration among economic growth, population, railway lines, and inflation is rejected at a 5 percent significance level. The presence of cointegration implies that there is a dynamic long-run causal relationship among the variables. 
Table 7. Unrestricted Cointegration Rank Test (Trace)

\begin{tabular}{lllll}
\hline Hypothesized & & Trace & 0.05 & \\
\hline No. of C.E. (s) & Eigenvalue & Statistic & Critical Value & Prob.** \\
\hline None $*$ & 0.657648 & 87.97117 & 47.85613 & 0.0000 \\
\hline At most $1 *$ & 0.521600 & 51.52606 & 29.79707 & 0.0000 \\
\hline At most $2 *$ & 0.410952 & 26.45758 & 15.49471 & 0.0008 \\
\hline At most 3 $*$ & 0.220355 & 8.463174 & 3.841465 & 0.0036 \\
\hline
\end{tabular}

Trace test shows 4 cointegrating eqn(s) at the 0.05 level

Source: Calculated by author(s)

Table 8. Unrestricted Cointegration Rank Test (Maximum Eigenvalue)

\begin{tabular}{|c|c|c|c|c|}
\hline Hypothesized & & Max-Eigen & 0.05 & \\
\hline No. of C.E. (s) & Eigenvalue & Statistic & Critical Value & Prob. ${ }^{\star *}$ \\
\hline None* & 0.657648 & 36.44511 & 27.58434 & 0.0028 \\
\hline At most $1^{*}$ & 0.521600 & 25.06848 & 21.13162 & 0.0132 \\
\hline At most $2^{*}$ & 0.410952 & 17.99441 & 14.26460 & 0.0123 \\
\hline At most $3 *$ & 0.220355 & 8.463174 & 3.841465 & 0.0036 \\
\hline
\end{tabular}

Max-eigenvalue test shows 4 cointegrating eqn(s) at the 0.05 level

Source: Calculated by author(s)

Once the variables are cointegrated, the VEC model can be performed. The lag order of the VAR is 2, and so the VECM's lag order should be 1 (see Table 9). The cointegration equation of the VEC model is shown below:

$$
\begin{array}{ccc}
\text { GROWTH }_{t-1}=-1.381406 P O P_{t-1}+ & 0.194654 R A I L_{t-1}+ & 0.072326 I N F_{t-1}+13.53295 \\
{[-2.51472]} & {[5.45629]} & {[0.36844]}
\end{array}
$$

The long-run results indicate a positive and statistically significant effect of railway lines on economic growth. It was observed that a one percent increase in railway lines leads to about $0.194 \%$ increase in economic growth in the long run, suggesting that investments in railway network promote economic growth. The study also found a negative and statistically relationship between population and economic growth, although this was not expected. The coefficient of inflation was positive and insignificant in explaining economic growth in the long run.

Table 9. VECM Results (Short-Run Estimates)

\begin{tabular}{lcccc}
\hline Variable & DGDP & DPOP & DRAIL & DINF \\
\hline CointEq(-1) & -0.350648 & 0.002963 & 0.418280 & -0.044181 \\
\hline & {$[-8.00128]$} & {$[0.96712]$} & {$[1.39168]$} & {$[-0.96310]$} \\
\hline DGDP(-1) & 0.206608 & 0.004668 & 0.024373 & 0.181570 \\
\hline & {$[2.26004]$} & {$[0.73042]$} & {$[0.03887]$} & {$[1.89743]$} \\
\hline DPOP(-1) & -2.891140 & 0.969226 & 0.958083 & -0.080036 \\
\hline & {$[-2.72978]$} & {$[13.0899]$} & {$[0.13190]$} & {$[-0.07219]$} \\
\hline DRAIL(-1) & 0.084434 & -0.002117 & -0.078778 & 0.010591 \\
\hline & {$[2.76482]$} & {$[-0.99138]$} & {$[-0.37613]$} & {$[0.33132]$} \\
\hline DINF(-1) & -0.813770 & 0.014882 & 0.341342 & 0.389960 \\
\hline $\mathrm{C}$ & {$[-7.27621]$} & {$[1.90339]$} & {$[0.44502]$} & {$[3.33101]$} \\
\hline & 0.066578 & -0.000310 & -0.024381 & 0.013729 \\
\hline $\mathrm{R}^{2}$ & {$[5.75080]$} & {$[-0.38343]$} & {$[-0.30707]$} & {$[1.13293]$} \\
\hline
\end{tabular}

Note: $\mathrm{t}$-Statistic in bracket.

Source: Calculated by author(s) 
Table 10. Diagnostic Test (VECM)

\begin{tabular}{lllc}
\hline Serial Correlation LM Test & Lag & F-stat & Prob. \\
\hline & 1 & 1.159073 & 0.3228 \\
\hline Heteroskedasticity Test & 2 & 0.827688 & 0.6506 \\
\hline
\end{tabular}

Source: Calculated by author(s)

The short-run results of the study are presented in Table 8. Similar to the long-run estimates, the short-run results also show evidence of a positive and one percent statistically significant relationship between economic growth and railway lines in quarter one. The results show that a one percentage point increase in railway lines leads to about a $0.084 \%$ increase in economic growth in the short run. More so, it was observed that a $1 \%$ increase in previous growth leads to about a $0.206 \%$ increase in current growth. In addition, a $1 \%$ increase in inflation and population decreases economic growth by about $0.81 \%$ and $2.89 \%$. The error correction term (ECT (-1)) or the speed of adjustment is negative as expected and statistically significant. The speed of adjustment value of 0.35 indicates that about $35 \%$ of the short-run disequilibrium is corrected in the long-run. The diagnostic test in Table 10 indicates that the model is free from serial correlation and heteroskedasticity.

Based on the VECM, the study carried out the Impulse Response analysis to examine the dynamic effects of the model due to shocks or innovations (see Figure 3). Shocks to railway lines or technology shock initially cause GDP growth rates to increase in the one period and then continue to decrease after the second period. Also, population and inflation shocks cause economic growth to decrease, attains a minimum after period 2, and then increase.

Figure 3. Impulse response Analysis.
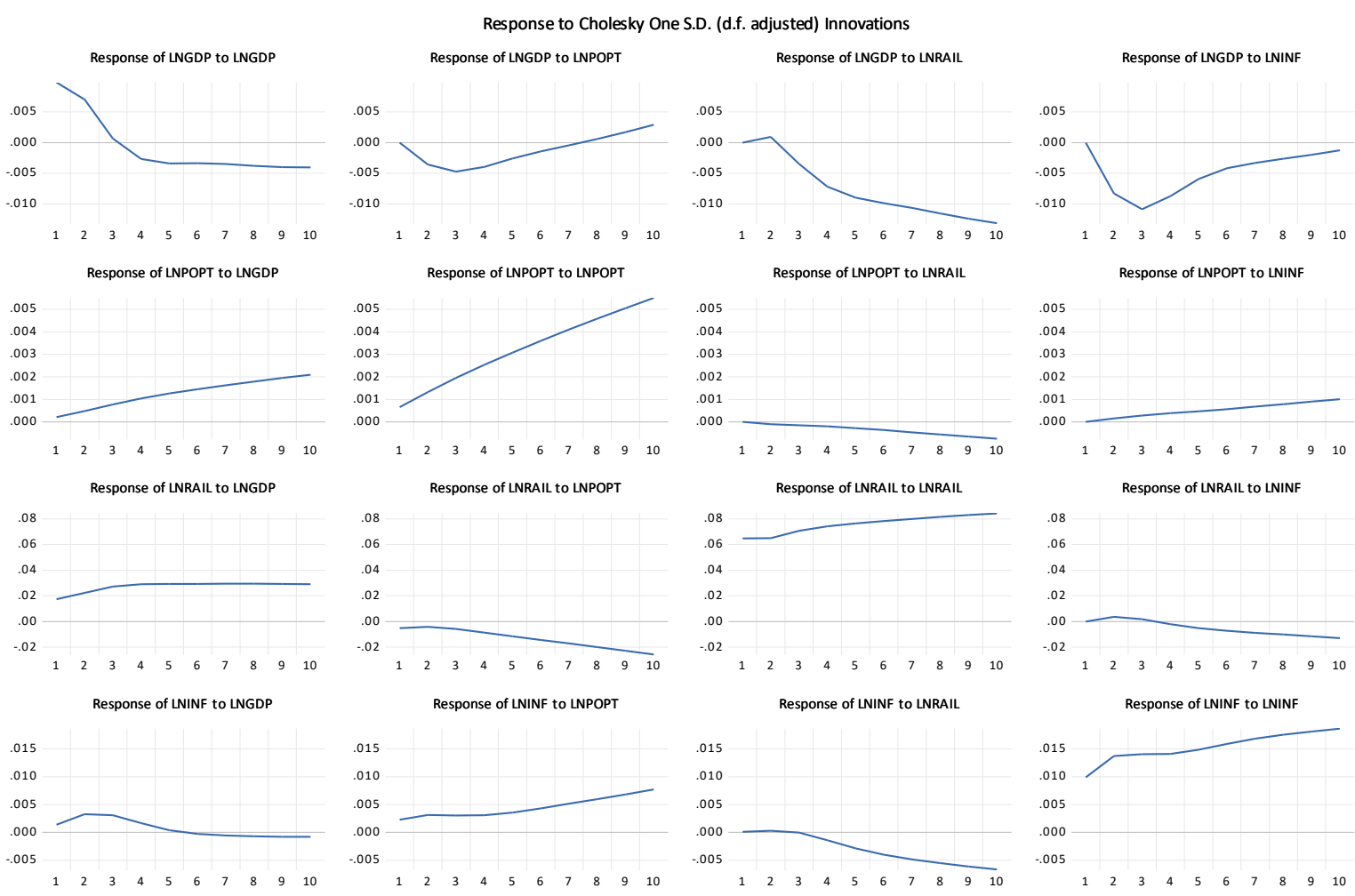

Source: Created by author(s)

More so, the variance decomposition analysis was carried out to examine the proportion of 
the explanatory variables to the total variations in economic growth for ten periods (see Figure 4). The variance decomposition of economic growth (GDP) indicates that railway lines alone contribute about $60 \%$ of the total variations in economic growth, followed by inflation and then population. This suggests that railway lines play a critical role in economic growth in the U.S.

Figure 4. Variance Decomposition Analysis.

Variance Decomposition using Cholesky (d.f. adjusted) Factors
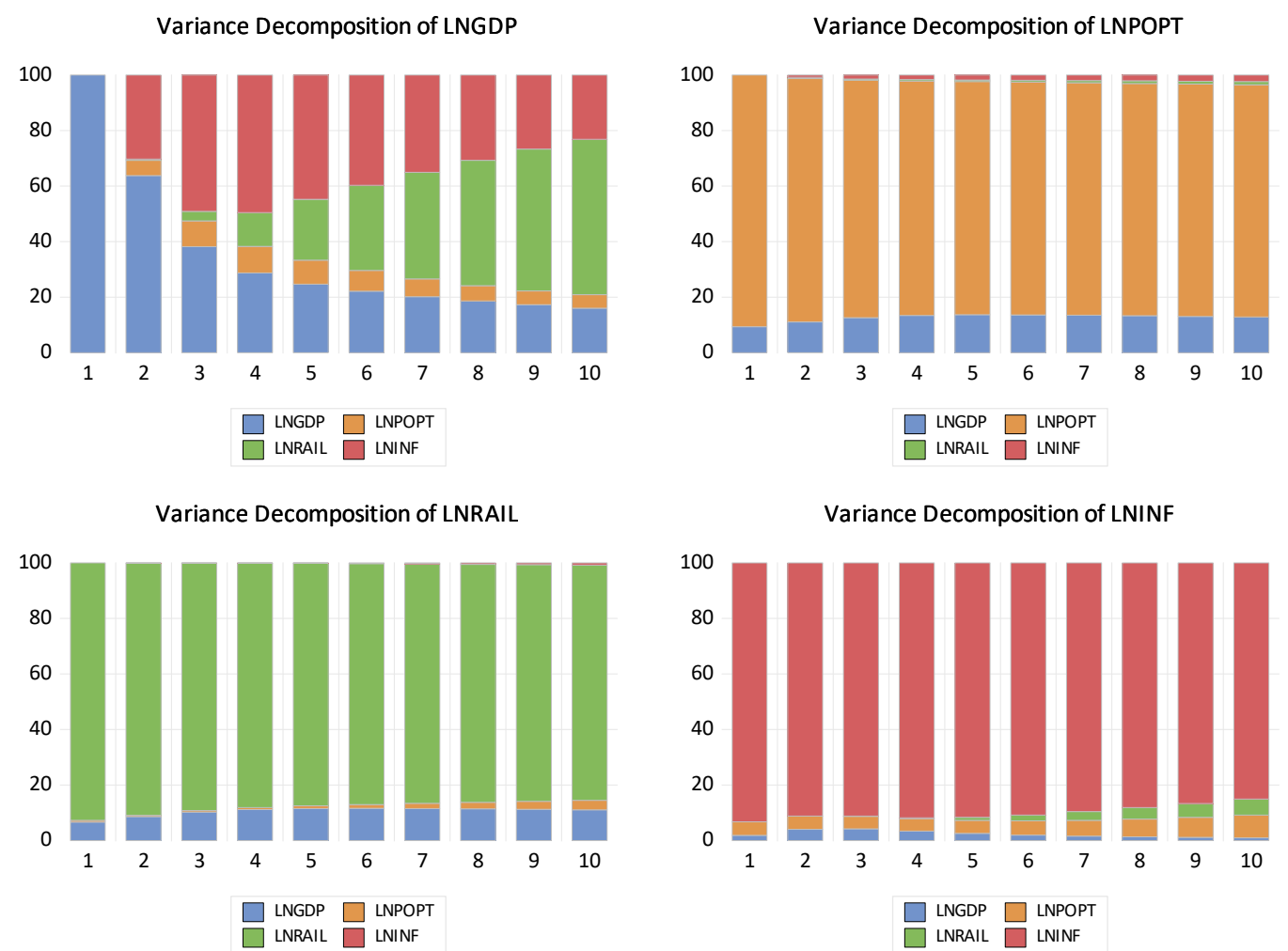

Source: Created by author(s)

\section{DISCUSSION}

The study finds a positive and significant effect of railway lines on economic growth in the U.S. In the long run, the study finds that $1 \%$ increase in railway lines leads to $0.194 \%$ increase in economic growth. Also, in the short run, the study finds that $1 \%$ increase railway lines increases economic growth by $0.084 \%$ in the U.S. The long run and short run results in this study are supported by the findings from variance decomposition (Figure 3) results which shows a significant contribution of railway lines to economic growth overtime. More so, this positive and significant effect of railway lines on economic growth is consistent with the study of Alam et al. (2020) who also found a positive effect of transportation infrastructure on economic growth in Pakistan. More so, the findings of this study are consistent with a number of cross-country studies. That is, the positive effect of railway line on economic growth is in line with the work of Pedroni (2004), Esfahani and Ramirez (2003), Czernich, Kretschmer, and Woessmann (2011), and Sridhar and Sridhar (2007) however, contradict the study by Palei (2015) who employed both a growth accounting framework and cross-country analysis and found no significant relationship between infrastructure, productivity, and growth in East Asia's economic growth. The results from this study suggest that investments in railway lines may be favorable to economic growth. More so, policy makers in developed and developing countries can adopt the findings of this study to formulate their policies. 


\section{CONCLUSIONS}

The main objective of this paper was to examine the effect of railway lines on economic growth in the U.S. using annual data from 1980-2016 and cointegration analysis. The results from the study revealed a positive and statistically significant effect of railway lines on economic growth in the long run and short run. Also, the impulse response analysis indicates that shocks to railway lines (technology shock) initially cause GDP growth rates to increase and then continuously decrease. The variance decomposition analysis also suggests that overtime, railway lines contribute largely to the variations in economic growth followed by inflation and population. For example, in period 10 , the variance decomposition results indicate that railway lines alone contribute nearly $60 \%$ to the total variations in economic growth hence, suggesting that railway lines matter for economic growth. This study is valuable because it examines the impact of railway lines on economic growth in the U.S. The outcome of this study also has important implications not only for the U.S. economy but also for developing and emerging countries. That is, policy makers can rely on the outcome of this study to design policies that will boost the railway lines and increase economic growth. Based on these findings, the study recommends increased investments in railway lines to increase economic growth in the U.S. Also, it is likely that state-level variations in railway lines spending could explain why some states do better economically than others. As a result, the study recommends future studies to use U.S. state-level data and panel analysis to examine to effect of railway lines on economic growth. 


\section{REFERENCES}

American Society of Civil Engineers, ASCE (2017). Closing the Infrastructure Gap for America's Economics Future. Accessed from https://www.infrastructurereportcard.org/wp-content/uploads/2016/10/ASCE-Failure-toAct-2016-FINAL.pdf Date Accessed: 02/23/2019

Alam, K. M., Li, X., Baig, S., Ghanem, O., \& Hanif, S. (2020). Causality between transportation infrastructure and economic development in Pakistan: An ARDL analysis. Research in Transportation Economics, 100974. https://doi.org/10.1016/j.retrec.2020.100974

Aschauer, D. A. (1989). Is public expenditure productive? Journal of monetary economics, 23(2), 177-200. https://doi.org/10.1016/0304-3932(89)90047-0 Association of American Railroads (2020). Freight rail powerful economic impact. AAR-Economic-Impact-Fact-Sheet.pdf

Banerjee, A., Duflo, E., \& Qian, N. (2012). On the road: Access to transportation infrastructure and economic growth in China (No. w17897). National Bureau of Economic Research. DOI 10.3386/w17897

Canning, D. (1998). A database of world stocks of infrastructure, 1950-95. The World Bank Economic Review, 12(3), 529-547. Data Sets | David Canning's Faculty Website | Harvard T.H. Chan School of Public Health

Canning, D., \& Pedroni, P. (2004). The effect of infrastructure on long run economic growth. Harvard University, 1-30. Does Infrastructure Cause Economic Growth (williams.edu)

Center for Strategy and International Studies (CSIS). (2020). Quality Infrastructure. Retrieved from Quality Infrastructure | Center for Strategic and International Studies (csis.org)

Cronin, F. J., Parker, E. B., Colleran, E. K., \& Gold, M. A. (1991). Telecommunications infrastructure and economic growth: An analysis of causality. Telecommunications policy, 15(6), 529-535. https://doi.org/10.1016/0308-5961(91)90007-X

Czernich, N., Falck, O., Kretschmer, T., \& Woessmann, L. (2011). Broadband infrastructure and economic growth. The Economic Journal, 121(552), 505-532. https://doi.org/10.1111/j.1468-0297.2011.02420.x

Dovell, E. (2012). U.S. Rail Infrastructure. U.S. Rail Infrastructure | Council on Foreign Relations (cfr.org)

Esfahani, H. S., \& Ramírez, M. T. (2003). Institutions, infrastructure, and economic growth. Journal of development Economics, 70(2), 443-477. https://doi.org/10.1016/S0304-3878(02)00105-0

Fosu, P. (2016). Infrastructure and Foreign Direct Investment Inflows: Evidence from Ghana. Management and Economic Journal, 93-106. Infrastructure and Foreign Direct Investment Inflows: Evidence from Ghana - Munich Personal RePEc Archive (uni-muenchen.de)

Fosu, P. (2019). The Determinants of Economic Growth: The Role of Infrastructure. Retrieved from MPRA_paper_93101.pdf (uni-muenchen.de)

Granger, C. W., Newbold, P., \& Econom, J. (2001). Spurious regressions in econometrics. A Companion to Theoretical Econometrics, Blackwell, Oxford, 557-561.

MacKinnon, J. G. (1996). Numerical distribution functions for unit root and cointegration tests. Journal of applied econometrics, 11(6), 601-618. https://doi.org/10.1002/(SICI)1099-1255(199611)11:6<601::AID-JAE417>3.0. C.O.;2-T

McBride, J. and Moss, J. (2020). The State of U.S. Infrastructure. Retrived from The State of U.S. Infrastructure | Council on Foreign Relations (cfr.org)

Palei, T. (2015). Assessing the impact of infrastructure on economic growth and global competitiveness. Procedia Economics and Finance, 23(2015), 168-175. https://doi.org/10.1596/1813-9450-4589 
Johansen, S. (1991). Estimation and hypothesis testing of cointegration vectors in Gaussian vector autoregressive models. Econometrica: journal of the Econometric Society, 1551-1580. https://www.jstor.org/stable/2938278

Johansen, S. (1992). Determination of cointegration rank in the presence of a linear trend. Oxford Bulletin of Economics and Statistics, 54(3), 383-397.

LAU, S. H. P., \& SIN, C. Y. (1997). Public infrastructure and economic growth: timeseries properties and evidence. Economic Record, 73(221), 125-135. https://doi.org/10.1111/j.1475-4932.1997.tb00986.x

Robert, S. P., \& Daniel, L. R. (1998). Econometric models and economic forecasts. New York, NY: Irwin and McGraw-Hill.

Sridhar, K. S., \& Sridhar, V. (2007). Telecommunications infrastructure and economic growth: Evidence from developing countries. Applied Econometrics and International Development, 7(2). Telecommunications Infrastructure and Economic Growth: Evidence from Developing Countries by Kala Seetharam Sridhar, Varadharajan Sridhar :: SSRN

Holtz-Eakin, D., \& Schwartz, A. E. (1995). Spatial productivity spillovers from public infrastructure: evidence from state highways. International Tax and Public Finance, 2(3), 459-468. DOI 10.3386/w5004

World Economic Forum (2016). Global Infrastructure Gap. Accessed from: http://reports.weforum.org/strategic-infrastructure-2014/introduction-the-operations-andmaintenance-om-imperative/the-global-infrastructure-gap. Date Accessed: 02/23/2019

World Economic Forum (2019). Global Infrastructure Gap. Accessed from: http://reports.weforum.org/strategic-infrastructure-2014/introduction-the-operations-andmaintenance-om-imperative/the-global-infrastructure-gap. Date Accessed: 12/27/2020.

World Development Indicators (WDI). (2020). Databank. World Development Indicators | DataBank (worldbank.org) 